\title{
Research and Development Investment and Earnings Quality Based on Regression Analysis
}

\author{
Hongwei Cheng ${ }^{1}$, Xi Peng*2 \\ ${ }^{1}$ Business School Sichuan University Chengdu, China \\ ${ }^{2}$ Business School Sichuan University Chengdu, China
}

\begin{abstract}
Based on the big data of Chinese listed manufacturing firms, we examine the relationship between research and development (R\&D) investment and earnings quality. We construct a regression model and find that corporate $R \& D$ investment has a positive effect on earnings quality. R\&D investment is useful to repress earnings management motives and thus improve earnings quality in listed manufacturing firms in China. And this positive correlation is more significant in state-owned firms than that in non-state-owned firms.
\end{abstract}

\section{Introduction}

Is $R \& D$ investment a tool for earnings management or for improving the quality of earnings? The relationship between R\&D investment, corporate value and corporate performance has been widely concerned. Generally, the impact of R\&D investment on the development of enterprises starts from the performance level and profitability. Bushee (1998) regarded R\&D investment as a key indicator to measure the long-term value of an enterprise [1]. Arrow (1962) [2] and Aghion and Howitt (1992) [3] believed that although R\&D activities will cause external economy and increase corporate economic risks, enterprises can also obtain positive spillover effects and benefit from R\&D activities of other enterprises and even other industries. The positive effect of $R \& D$ investment in national development, industrial upgrading and enterprise growth has been widely recognized. From a macro-economic perspective, Blanco et al. (2016) proposed that $R \& D$ can promote a country's economic growth through total factor production in the long run [4]. At the micro level, García-Manjón and Romero-Merino (2012) [5], Warusawitharana (2015) [6], Zhao et al. (2016) [7] believed that R\&D investment can promote technological progress and corporate sales growth, and greatly improve the profitability and corporate value of enterprises. Tang (2015) found that even in the economic downturn, increasing $R \& D$ investment intensity is also conducive to improving enterprise performance, especially for manufacturing enterprises [8].

Although profitability can reflect the operating performance of an enterprise in a certain period, it is the earnings quality that truly reflects the long-term development and corporate value, and is used for performance prediction and investor decision-making. Earnings quality is a true reflection of the corporate basic earnings characteristics related to investors' specific decisions. High-quality earnings can provide more information about corporate financial performance which is useful for specific decisions or future prediction, and can better reflect the future development of enterprises (Ball and Shivakumar, 2005 [9], 2008 [10]; Dechow et al. 2010 [11]). However, current research on relation between $R \& D$ investment and earnings quality mainly focuses on how management influence earnings quality. One way is to capitalize or expense R\&D expenditure through accounting choice. Some scholars believe that capitalization of R\&D expenditure can improve value relevance of accounting information, and can enhance corporate market value (Ahmed and Falk, 2006 [[13]). Others believe that accounting treatment of R\&D expenditure provides the space for earnings management, and the management may increase earnings noise by manipulating the capitalization of R\&D expenditure, and thus damage the value relevance of accounting information (Cazavan-Jeny and Jean, 2006 [14]; Markarian et al., 2008 [15]). Another way is to balance the amount of R\&D investment to affect the quality of earnings. Huang and Chen (2014) demonstrated a positive correlation between $\mathrm{R} \& \mathrm{D}$ investment and earnings sustainability, and propose that firms should increase $R \& D$ efforts in order to improve earnings sustainability [16]. R\&D investment can also bring policy benefits, such as tax preference and government subsidies, to enterprises. Wang and Wang (2015) found that corporate R\&D investment has tax shield value [17], and enterprises can adjust the amount of tax payment by managing R\&D expenditure. Weiss et al. (2013) found that earnings volatility caused by low-innovative product is similar to that caused by asset capital investment [18].

We find that most of the literature on the judgment of corporate performance is based on traditional financial indicators, which can only reflect the short-term earnings level of the company, but cannot reflect the long-term development ability of the company. In addition, excluding the regulatory function of $R \& D$ expenditure,

* Corresponding author: px2727@126.com 
there are few studies on R\&D investment and earnings quality. Moreover, accounting policies and enterprise types of the countries where the research samples are located are different. Therefore, there is no consistent conclusion. Based on relevant research, we study the impact of R\&D expenditure on earnings quality, and find that $R \& D$ investment in China's manufacturing listed companies is not completely a tool for earnings management, but can effectively improve corporate earnings quality. Furthermore, R\&D investment has a more significant impact on earnings quality in state-owned firms.

\section{Theoretical analysis and research hypothesis}

Based on contract theory and information view, agency problem is the main reason for earnings management. In order to maximize personal interests, management makes opportunistic behaviors that damage interests of the firm and other stakeholders ( $\mathrm{Ni}$ and Huang, 2014 [19]). However, without considering the rationality of the incentive mechanism, the fundamental reason for management to manipulate earnings is that the firm's value creation ability is insufficient, and the firm's own development cannot meet market expectations. The promotion of enterprise value creation ability needs to be driven by $R \& D$ behavior. The promotion of $R \& D$ is mainly reflected in the promotion of production efficiency and innovation ability. Wakelin (2001) [20], Sharma (2012) [21], O'mahony and Vecchi (2009) [22] showed that there is a significant positive relationship between R\&D investment intensity and corporate productivity. R\&D investment can promote the improvement of total factor productivity. Industries with high R\&D investment have higher productivity. At the same time, as a knowledge production function, R\&D has spillover effect (Acs et al., 1992 [23]; Mailesse and Mohnen, 2005 [24]). Barge-Gil and Lopez (2014) also proposed that even if there is a gap in the nature and purpose of research activities and development activities, they can promote the innovation output of enterprises [25]. Production efficiency and innovation ability are the internal development capabilities of enterprises, which promote the value creation of enterprises for a long time. Chun et al. (2016) demonstrated the positive effect of enterprise total factor productivity on enterprise stock return rate [26]. Taking Chinese pharmaceutical manufacturing industry as an example, Wang et al. (2012) concluded that innovation can help manufacturing enterprises realize business expansion in the value chain and improve profitability [27] Therefore, firms that pay attention to $R \& D$ investment tend to pay more attention to the long-term development of enterprises, and are less likely to have short-term behavior such as earnings manipulation, and thus earnings quality is relatively higher. Therefore, we propose hypothesis 1 .

Hypothesis 1: higher R\&D expenditure lead to the lower degree of earnings management and the higher earnings quality.
State-owned firms occupy an important position in national economy in China. Compared with non-stateowned firms, state-owned firms have several advantages. First, compared with non-state-owned firms, stateowned firms usually have more government resources. And the firms scale is relatively larger. Many scholars shows that there is a positive correlation between firm size and R\&D efficiency ( $\mathrm{Zhu}$ and $\mathrm{Xu}, 2006$ [28]; Yu, 2011 [29]; Zhou and Deng, 2009 [30]). Second, compared with non-state-owned firms, state-owned firms have monopoly competitive advantages in some industries. China's stateowned firms have the advantages of complete monopoly or oligopoly in water, electricity, oil, natural gas and other industries that control the lifeline of the national economy. Xiao and Lin (2014) believed that monopoly advantage helps firms invest more into R\&D activities and enjoy the excess profits generated by $R \& D$ [31]. Third, the ownership nature determines that state-owned firms obtain more government resources and support. Hamberg (1966) [32], Xie et al. (2009) [33] believed that compared with non-state-owned firms, state-owned firms' R\&D activities are easier to obtain policy benefits. Compared with nonstate-owned firms, state-owned firms have more prominent $\mathrm{R} \& \mathrm{D}$ advantages, and $\mathrm{R} \& \mathrm{D}$ activities have multiplier effect. Under this conditions, state-owned firms are more lack of earnings management motivation, and the earnings quality is higher. Therefore, we propose hypothesis 2 .

Hypothesis 2: compared with non-state-owned firms, the positive correlation between $R \& D$ expenditure and earnings quality in state-owned firms is more significant.

\section{Research Design}

\subsection{Model design}

Researchers mainly use seven indicators to measure earnings quality: accrual quality, sustainability, predictability, smoothness, value relevance, timeliness and robustness. Among these seven indicators, Francis et al. (2004) believed that accrual quality, persistence, predictability and smoothness could better reflect earnings quality [34]. Ma et al. (2011) put forward that persistence, predictability and smoothness have high requirements on time windows and need time series data with long time windows [35]. However, China's capital market is inefficient and information interference is serious (Ma et al., 2011 [35]). At the same time, the economic environment and accounting policies are continuing changing (Ma et al., 2011 [35]). Therefore, we use accrual quality as the proxy of earnings quality. According to Dechow and Dichev (2002) [36], we use model (1) and model (2) to calculate accrual quality.

$$
\begin{gathered}
\frac{T C A_{i, t}}{T A_{i, t}}=\lambda+\varphi_{1, i} \frac{C F O_{i, t-1}}{T A_{i, t}}+\varphi_{2, i} \frac{C F O_{i, t}}{T A_{i, t}}+\varphi_{3, i} \frac{C F O_{i, t+1}}{T A_{i, t}}+\theta_{i, t} \\
T C A_{i, t}={ }_{\Delta} C A_{i, t}-\Delta C L_{i, t}-\Delta C F O_{i, t}+\Delta S T D_{i, t}
\end{gathered}
$$


$T C A_{i, t}$ denotes total accrual of firm $i$ in period $t$. $C F O_{i, t}$ 1, $C F O_{i, t}, C F O_{i, t+l}$ are operating cash flow of firm $i$ in period $t-1$, period $t$ and period $t+1$, respectively. $T A_{i, t}$ presents total assets of firm $i$ in period $t . \Delta C A_{i, t}$ is the change of current assets of firm $i$ period $t . \Delta C L_{i, t}$ is the change of current liabilities of firm $i$ in period $t . \triangle C F O_{i, t}$ is the change of operating cash flow of firm $i$ in period $t$. $\triangle S T D_{i, t}$ is the change of short-term liabilities of firm $i$ in period $t$. The larger the absolute value of $\theta_{i, t}$ is, the worse the accrual quality is and the lower the earnings quality is.

There are two main indicators to measure $R \& D$ Expenditure: (1) annual R\&D expenses / total assets (Huang and Chen, 2011 [37]); and (2) annual R\&D expenses / annual operating revenue. We select the first method to measure corporate $R \& D$ expenditure. We use model (3) to test hypothesis 1 and hypothesis 2 .

$$
\begin{aligned}
& A Q_{i, t}=\alpha+\beta_{1, i} R D_{i, t}+\beta_{2, i} \operatorname{SIZE}_{i, t}+\beta_{3, i} N I B E_{i, t} \\
& +\beta_{4, i} \mathrm{CFO}_{i, t}+\beta_{5, i} \text { GROWTH }_{i, t}+\beta_{6, i} \text { ROA }_{i, t} \\
& +\beta_{7, i} O P C Y C L E_{i, t}+\beta_{8, i} L E V_{i, t}+\beta_{9, i} B M_{i, t} \\
& +\beta_{10, i} C A P E X_{i, t}+\varepsilon
\end{aligned}
$$

$A Q$ is dependent variable and presents accrued quality. $R D$ is independent variable and presents corporate $\mathrm{R} \& \mathrm{D}$ expenditure. Others are control variables. Size is the firm size which equals to the natural logarithm of total assets. NIBE and CFO are the volatility of key earnings and the volatility of operating cash flow, which are reflected by the standard deviation of the key earnings or operating cash flow, and adjusted by the total assets, respectively. The larger the standard deviation is, the greater the volatility of key earnings and operating cash flow is. GROWTH is the increase of the firms' operating income. $R O A$ is return on net assets. OPCYCLE is corporate business cycle. $L E V$ is corporate leverage. $B M$ is book to market ratio, which equals to the total market value of the enterprise divided by the book value of the equity assets. $C A P E X=$ non-current assets / total assets. To avoid the influence of extreme values, all variables are winsorized at the level of 0.01 .

\subsection{Sample selection and data sources}

According to the industry classification of China Securities Regulatory Commission, our initial sample is all listed manufacturing companies from 2007 to 2015, which includes 635 firms and 6350 "firm-year" observations. We exclude ST and *ST firms, firms with missing data and discontinuous data. The final sample consists of 126 firms and 882 "firm-year" observations. There are 63 stateowned firms and 63 non-state-owned enterprises All data are obtained from WIND database.

\section{Main empirical results}

\subsection{Descriptive statistics}

The descriptive statistics of main variables are shown in Table 1. The mean and standard deviation of $A Q$ of all firms are 0.1309 and 0.0536 , respectively, which indicates that the overall earnings manipulation degree of sample enterprises is low and the earnings quality is generally high. The average value of $R D$ is 0.0180 , and the standard deviation is 0.0159 , indicating that the proportion of $R \& D$ expenditure of sample is generally low.

According to the classification of ownership, we find that the $R D$ of state-owned firms is generally higher than

\begin{tabular}{|c|c|c|c|c|c|}
\hline Variables & $\mathbf{N}$ & Mean & SD & Min & Max \\
\hline \multicolumn{6}{|c|}{ Panel A: all firms } \\
\hline$A Q$ & 882 & 0.1309 & 0.0536 & 0.0122 & 0.2804 \\
\hline$R D$ & 882 & 0.0180 & 0.0159 & 0.0002 & 0.0806 \\
\hline SIZE & 882 & 22.1731 & 1.1646 & 20.010 & 25.5181 \\
\hline NIBE & 882 & 0.0315 & 0.0234 & 0.0037 & 0.1257 \\
\hline $\mathrm{CFO}$ & 882 & 0.0306 & 0.0202 & 0.0088 & 0.1269 \\
\hline GROWTH & 882 & 0.1477 & 0.2425 & -0.3716 & 1.0790 \\
\hline$R O A$ & 882 & 0.0624 & 0.0480 & -0.0631 & 0.2020 \\
\hline OPCYCLE & 882 & 5.0725 & 0.6876 & 3.4065 & 6.7286 \\
\hline$L E V$ & 882 & 0.0885 & 0.0803 & 0.0011 & 0.3397 \\
\hline$B M$ & 882 & 0.4733 & 0.4891 & 0.0776 & 3.7711 \\
\hline CAPEX & 882 & 0.2697 & 0.1359 & 0.0505 & 0.6236 \\
\hline \multicolumn{6}{|c|}{ Panel B: state-owned firms } \\
\hline$A Q$ & 441 & 0.1365 & 0.0595 & 0.0453 & 0.2804 \\
\hline$R D$ & 441 & 0.1812 & 0.0151 & 0.0002 & 0.0806 \\
\hline SIZE & 441 & 22.2872 & 1.1327 & 20.0096 & 25.5182 \\
\hline NIBE & 441 & 0.0345 & 0.0285 & 0.0037 & 0.1257 \\
\hline $\mathrm{CFO}$ & $\overline{441}$ & 0.0346 & 0.0256 & 0.0094 & 0.1269 \\
\hline GROWTH & 441 & 0.1411 & 0.2307 & -0.3716 & 1.0798 \\
\hline$R O A$ & $\overline{441}$ & 0.0565 & 0.0471 & -0.0631 & 0.2029 \\
\hline OPCYCLE & 441 & 5.0757 & 0.7007 & 3.4065 & 6.7286 \\
\hline$L E V$ & 441 & 0.0926 & 0.0820 & 0.0011 & 0.3397 \\
\hline$B M$ & 441 & 0.4877 & 0.4302 & 0.0776 & 3.7711 \\
\hline CAPEX & 441 & 0.2728 & 0.1371 & 0.0505 & 0.6236 \\
\hline \multicolumn{6}{|c|}{ Panel C: non-state-owned firms } \\
\hline$A Q$ & 441 & 0.1252 & 0.0462 & 0.0122 & 0.2246 \\
\hline$R D$ & 441 & 0.0179 & 0.0166 & 0.0002 & 0.0806 \\
\hline SIZE & 441 & 22.0590 & 1.1859 & 20.0096 & 25.5182 \\
\hline NIBE & 441 & 0.0285 & 0.0162 & 0.0037 & 0.0785 \\
\hline$C F O$ & 441 & 0.0267 & 0.0114 & 0.0088 & 0.0586 \\
\hline GROWTH & $\overline{441}$ & 0.1543 & 0.2539 & -0.3716 & 1.0798 \\
\hline$R O A$ & 441 & 0.0683 & 0.0483 & -0.0631 & 0.2029 \\
\hline OPCYCLE & 441 & 5.0692 & 0.6750 & 3.4065 & 6.7286 \\
\hline$L E V$ & 441 & 0.0844 & 0.0784 & 0.0011 & 0.3397 \\
\hline$B M$ & 441 & 0.4588 & 0.5417 & 0.0776 & 3.7711 \\
\hline CAPEX & 441 & 0.2663 & 0.1348 & 0.0505 & 0.6236 \\
\hline
\end{tabular}
that of non-state-owned firms. It indicates that stateowned firms pay more attention to R\&D investment.

Table1. Descriptive Statistics Of Main Variables

\subsection{Regression analysis}

The regression results are shown in Table 2. We can find that $R D$ and $A Q$ are significantly negatively correlated at the level of $\mathrm{p}<0.05$. It indicates that the higher the $R \& D$ expenditure is, the smaller the motivation of earnings management is, and the higher the earnings quality is. The results support hypothesis 1 .

There is a significant negative correlation with coefficient of -0.2501 between $R D$ and $A Q$ in state-owned enterprises at the level of $\mathrm{p}<0.1$, which is higher than the whole sample level. While the correlation coefficient of $R D$ and $A Q$ of non-state-owned enterprises is -0.1765 , but it fails to pass significance test. The results support hypothesis 2 that the positive effect of $R \& D$ expenditure on earnings quality of state-owned enterprises is greater than that of non-state-owned enterprises, and the driving force of R\&D expenditure on earnings quality is more obvious. 
Table2. Regression results

\begin{tabular}{|c|c|c|c|}
\hline Variables & All firms & $\begin{array}{l}\text { state-owned } \\
\text { firms }\end{array}$ & $\begin{array}{c}\text { Non-state- } \\
\text { owned firms }\end{array}$ \\
\hline$R D$ & $\begin{array}{c}-0.2191^{* *} \\
(-2.36)\end{array}$ & $\begin{array}{c}-0.2501 * \\
(-1.75)\end{array}$ & $\begin{array}{l}-0.1765 \\
(-1.49) \\
\end{array}$ \\
\hline SIZE & $\begin{array}{c}-0.0029^{* *} \\
(-2.23)\end{array}$ & $\begin{array}{c}-0.0052 * * * \\
(-2.63)\end{array}$ & $\begin{array}{l}-0.0020 \\
(-1.17)\end{array}$ \\
\hline NIBE & $\begin{array}{c}-0.1597 * * \\
(-2.22)\end{array}$ & $\begin{array}{c}-0.3748 * * * \\
(-3.83)\end{array}$ & $\begin{array}{c}0.3398^{* * * *} \\
(2.75)\end{array}$ \\
\hline$C F O$ & $\begin{array}{c}1.6105 * * * \\
(19.65)\end{array}$ & $\begin{array}{c}1.6844^{* * *} \\
(15.85)\end{array}$ & $\begin{array}{c}1.8780 * * * \\
(11.05)\end{array}$ \\
\hline GROWTH & $\begin{array}{c}0.0116^{*} \\
(1.80)\end{array}$ & $\begin{array}{c}0.0203 * * \\
(2.05)\end{array}$ & $\begin{array}{l}0.0052 \\
(0.63)\end{array}$ \\
\hline$R O A$ & $\begin{array}{l}0.0353 \\
(1.08)\end{array}$ & $\begin{array}{l}0.0777 \\
(1.59)\end{array}$ & $\begin{array}{l}-0.0155 \\
(-0.35)\end{array}$ \\
\hline OPCYCLE & $\begin{array}{c}-0.0066 * * * \\
(-2.87)\end{array}$ & $\begin{array}{c}-0.0108 * * * \\
(-3.20)\end{array}$ & $\begin{array}{l}-0.0017 \\
(-0.55)\end{array}$ \\
\hline$L E V$ & $\begin{array}{l}-0.0182 \\
(-0.97)\end{array}$ & $\begin{array}{l}-0.0287 \\
(-1.04)\end{array}$ & $\begin{array}{l}-0.0294 \\
(-1.16)\end{array}$ \\
\hline$B M$ & $\begin{array}{c}-0.0067^{* *} \\
(-2.22) \\
\end{array}$ & $\begin{array}{l}-0.0022 \\
(-0.44) \\
\end{array}$ & $\begin{array}{c}-0.0096^{* * *} \\
(-2.64)\end{array}$ \\
\hline CAPEX & $\begin{array}{l}-0.0170 \\
(-1.41)\end{array}$ & $\begin{array}{c}-0.0351^{* *} \\
(-1.98)\end{array}$ & $\begin{array}{l}0.0062 \\
(0.39)\end{array}$ \\
\hline
\end{tabular}

Note:***, ${ }^{* *}, *$ denote statistical significance at $1 \%, 5 \%$ and $10 \%$, respectively.

\section{Conclusions}

Based on the empirical research on relationship between $\mathrm{R} \& \mathrm{D}$ expenditure and earnings quality of listed manufacturing firms from 2007 to 2015 , we find that there is a positive correlation between R\&D investment and earnings quality of listed firms. $R \& D$ investment can effectively inhibit the earnings manipulation motivation of management and promote earnings quality. Compared with non-state-owned firms, state-owned firms pay more attention to R\&D investment. The positive effect of $R \& D$ investment on earnings quality of state-owned firms is significantly higher than that of non-state-owned firms.

We provide a supplementary study on the impact of $R \& D$ investment on earnings management and earnings quality. The study also has policy implications. Under the background of "Industry 4.0" and "Made in China 2025", Chinese manufacturing firms should pay more attention to $R \& D$ investment in order to improve total productivity and innovation ability, as well as restrain earnings management, and thus improve earnings quality and strengthen the ability of sustainable development.

\section{Reference}

1. $\mathrm{B}^{\mathrm{B}}$ ushee. "The influence of institutional investors on myopic R\&D investment behavior," Account. Rev., vol. 73, pp. 305-333. (1998).

2. K Arrow. Economic welfare and the allocation of resources for invention. In The rate and direction of inventive activity: Economic and social factors. NJ: Princeton University Press, 1962.

3. P Aghion and P Howitt. "A model of growth through creative destruction," Econometrica, vol. 60, pp. 323351, 1992.

4. L Blanco, J Gu and J Prieger. "The impact of research and development on economic growth and productivity in the U.S. states," South. Econ. J., vol. 82, pp. 914-934, 2016.

5. J Garcia-Manjon and M Romero-Merino. "Research, development, and firm growth: empirical evidence from European top R\&D spending firms," Res. Policy, vol. 41, pp. 1084-1092, 2012.

6. M Warusawitharana. "Research and development, profits, and firm value: A structural estimation," Quant. Econ., vol. 6, pp. 531-565, 2015.

7. $\mathrm{C}$ Zhao, $\mathrm{X}$ Han and $\mathrm{W}$ Song. "P\&D input's heterogeneous effect effect on technological progress of the enterprises," Forum on Science and Technology in China, vol. 6, pp. 85-89, June 2016 [in Chinese]

8. S Tang. "Does research and development intensity enhance industrial performance during economic downturns? Inter-industry evidence from Australia," Aust. Econ. Rev., vol. 48, pp. 243-257, 2015.

9. R Ball and L Shivakumar. "Earnings quality in U.K. private firms: comparative loss recognition timeliness," J. Account. Econ., vol. 39, pp. 83-128, 2005.

10. R Ball and L Shivakumar. "Earnings quality at initial public offerings," J. Account. Econ., vol. 45, pp. 324349, 2008.

11. P Dechow, W Ge and C Schrand. "Understanding earnings quality: A review of the proxies, their determinants and their consequences," J. Account. Econ., vol. 50, pp. 344-401, 2010.

12. S Penman and $X$ Zhang. "Accounting conservatism, the quality of earnings, and stock returns," Account. Rev., vol. 77, pp. 237-264, 2002.

13. $\mathrm{K}$ Ahmed and H Falk. "The value relevance of management\&apos;s research and development reporting choice: evidence from Australia," J. Account. Public Policy., vol. 25, pp. 231-264, 2006.

14. A Cazavan-Jeny and $\mathrm{T}$ Jeanjean. "The negative impact of R\&D capitalization: a value relevance approach," Eur. Account. Rev., vol. 15, pp. 37-61, 2006.

15. G Markrian, L Pozza and A Prencipe. "Capitalization of R\&D costs and earnings management: Evidence from Italian listed companies," The International Journal of Accounting, vol. 43, pp. 246-267, 2008.

16. D Huang and $B$ Chen. "Research on R\&D investment and earnings persistence - Empirical evidence based on China's manufacturing listed companies," Commercial Accounting, vol. 22, pp. 31-36, November 2014 [in Chinese]

17. L Wang and $Y$ Wang. "R\&D investment and the choice of capital strcture - An analysis from the perspective of non-debt related tax shields," China Industrial economics, vol. 11, pp. 127-140, November 2015 [in Chinese]

18. D Weiss, H Falk and U Zion. "Earnings variability and disclosure of R\&D: Evidence from press releases," Account . Financ., vol. 53, pp. 837-865, 2013. 
19. M Ni and S Huang. "Non-opportunistic earnings management: Connotation analysis and commentary on its empirical research,". Journal of Audit and Economics, vol. 1, pp, 58-67, Januarary 2014 [in Chinese]

20. K Wakelin. "Productivity growth and R\&D expenditure in UK manufacturing firms," Res. Policy, vol. 30, pp. 1079-1090, 2001.

21. C Sharma. "R\&D and firm performance: evidence from the Indian pharmaceutical industry," Journal of the Asia Pacific Economy, vol. 17, pp. 332-342, 2012.

22. M O'Mahony and M Vecchi. "R\&D, knowledge spillovers and company productivity performance," Res. Policy, vol. 38, pp. 35-44, 2009.

23. Z Acs, D Audretsch and M Feldman. "Real effects of academic research: comment," Am. Econ. Rev., vol. 82, pp. 363-367, 1992.

24. J Mariesse and P Mohnen. "The importance of R\&D for innovation: a reassessment using French survey data," J. Technol. Transf., vol. 30, pp. 183-197, 2005.

25. A Barge-Gil, A Lopez. "R versus D: estimating the differentiated effect of research and development on innovation results," Ind. Corp. Change, vol. 24, pp. 93-129, 2014.

26. H Chun, J Kim and R Morck. Productivity growth and stock returns: firm- and aggregate-level analyses[J]. Appl. Econ., vol. 48, pp. 3644-3664, 2016.

27. W Wang, J Fu and Y Zhu. "Innovation, value chains and profitability of manufacturing industry - Based on Chinese pharmaceutical companies,". China Industrial Economics, vol. 4, pp. 50-62, April 2012 [in Chinese]

28. Y Zhu and $\mathrm{K} \mathrm{Xu}$. "The empirical research on R\&D efficiency of Chinese high-tech industries,". China Industrial Economics, vol. 11, pp. 38-45, November 2006 [in Chinese]

29. Y Yu. "Innovation cluster, government support and the technological innovation efficiency: Based on spatial econometrics of panel data with provincial data," Economic Review, vol. 2, pp. 93-101, March 2011 [in Chinese]

30. L Zhou and L Deng. "Research on the relationship between ownership and R\&D efficiency - Empirical study on China high-tech industries with SFA method' Modern Economic Science, vol. 4, pp. 70-75, July 2009 [in Chinese]

31. W Xiao and G Lin. "Government support, R\&D management and technological innovation efficiency: An empirical analysis based on Chinese industrial industry," Management World, vol. 4, pp. 71-80, April 2014 [in Chinese]

32. Hamberg. R\&D essays on economics of research and development. London: Random Publish House, 1966.

33. W Xie, Q Tang and S Lu. "Government R\&D funds, corporate $\mathrm{R} \& \mathrm{D}$ expenditure and independent innovation," Journal of Financial Research, vol. 6, pp. 86-99, June 2009 [in Chinese]
34. J Francis, R Lafond, P Olsson and K Schipper. Costs of equity and earnings attributes. Account. Rev., vol. 4, pp. 967-1010, 2004.

35. Z Ma, D Chen and H Zhang. "Differences in corporate characteristics, internal governance and earnings quality," Accounting Research, vol. 3, pp. 54-61, March 2011 [in Chinese]

36. P Dechow and I Dichev. The quality of accruals and earnings: the role of accrual estimation errors[J]. Account. Rev., vol. 77, pp. 35-59, 2002.

37. J Huang and $X$ Chen. "Business group $R \& D$ investment: An analysis from the perspective of knowledge spillover and internal capital market," $\mathrm{E}^{\text {conomic Research Journal, }}$ vol. 6, pp. 80-92, June ${ }^{2011}$ [in Chinese] 